\title{
THE WHALING CONVENTION
}

\section{By G. C. L. Bertram, Director of the Scott Polar Research Institute, Cambridge}

The International Convention for the Regulation of Whaling was signed in 1946. It is one of the better examples of healthy international co-operation. This brief article endeavours to give some indication of the scope of the Convention itself and of the Commission which meets annually. For further information it is most convenient to look first at the articles and notes which appear from time to time in the Polar Record and in Norsk Hvalfangst Tidende. The latter journal in its issue for July, 1952, sets out the Convention and its Schedules in full.

The actual Convention, as ratified by the countries concerned, starts with an encouraging preamble which fully recognizes the problem, the fact of over-fishing, and the need for permanent conservation. The Articles of the Convention determine the framework of the agreement: they define to whom the Convention applies; the definition of whaling ships; the organization of the Commission ; the organization of research statistics and publication; the amendment of Schedules; recommendations to Governments; the transmission of figures to the "International Bureau for Whaling Statistics" in Sandefjord ; the taking of whales for scientific purposes; the treatment by Governments of transgressions by their own nationals ; ratifications and withdrawal from the Commission. It is to be appreciated that though the Convention covers whaling throughout the world, in fact 90 per cent of present-day whaling takes place in the Southern Ocean.

Then the Schedule to the Convention specifies the actual rules which shall, in any particular year, govern the whaling itself. Arrangements are made for the provision of official inspectors by each country to serve with its own whaling expeditions. 'There is total prohibition of the killing of right whales and grey whales, and of the killing of sucklings and of females accompanied by sucklings. There is prohibition on all whaling in certain areas. There is a limitation of the taking of humpbacks to $\mathbf{1 , 2 5 0}$ animals as a world total. There is limitation of whaling in the Southern Ocean to a short season which shall start on a fixed day and shall end when the bureau in Sandefjord, having received radio information of all catches week by week, determines that the agreed total of 16,000 blue-whale-units will be reached. A longer season is allowed for the taking of sperm whales.

The Schedule to the Convention then determines the lower 
permissible lengths at which whales of different species may be killed, and the method of measurement. Then there are regulations covering the operation of the few remaining land stations and the adequate use of the whales killed so as to prevent waste of the less profitable products of the fishery. Next there are regulations for the proper recording of details of each whale killed and for the keeping of the necessary statistics. The Schedule ends with certain special arrangements to cover territorial waters and various definitions.

The Whaling Commission, the international body which operates the Convention, meets annually and has power to alter the regulations, under the Schedule, to govern the fishing in the ensuing year. The fourth of these annual meetings of the Commission took place in London in June, 1952, under the chairmanship of Ambassador Birger Bergersen who, under the rules, has now been replaced by Professor Remington Kellog. At present there are seventeen countries which originally ratified, or have later adhered to, the Convention. This number includes all those that matter in modern whaling and some that are of less significance. The U.S.S.R. ratified the Convention and plays a helpful part. The Commission has three permanent committees who deal with matters scientific, technical, financial and administrative.

At the fourth meeting of the Commission special attention was given to the highly important organization of future whalemarking activities now that the earlier work, almost entirely the effort of the British Discovery Investigations, has come to an end with the merging of that body in our new Institute of Oceanography.

The Commission has agreed again to allow the taking of 1,250 humpback whales. But, since in the last few years for administrative reasons that quota has been somewhat exceeded, it is now arranged that the humpback fishing shall be limited to the first three days of February and that the figures of catch shall be transmitted to Sandefjord daily. Humpback whales are believed to live in five fairly well defined groups and the Scientific Committee is to go further in trying to prepare a quota system to be applied separately in view of the fact that these several populations have suffered differently in the past.

Certain new statistical surveys are to be made so that the Scientific Committee can also proceed further with the fundamental consideration of the suitability, and the possibility, of a reduction of the annual quota below 16,000 blue-whale-units for the whole southern fishery. Further consideration too is to 
be given to the possibility of a total prohibition upon the taking of blue and fin whales from the greatly depleted stocks of the northern hemisphere.

The next meeting of the Whaling Commission will again be in London, in June, 1953. During the 1952-53 southern season, following a drop in the price of whale oil, there will probably be ten major expeditions at sea, a slight reduction from the figure a year previously. The season was to open on 2nd January, 1953, the latest date ever to be fixed for the opening. The later the annual quota of whales is taken from the Southern Ocean the fatter are the whales and the greater the yield of oil from the same number of whales.

In summary it may be said that the Whaling Commission is a remarkably successful body working a sensible Convention with honesty and worthy purpose. The limitation to 16,000 blue-whale-units represents a fixing of the yield of the fishery at about two-thirds of the average pre-war take of 500,000 tons of whale oil. There remains the basic problem of whether, in view of pre-war depletion of the stock, 16,000 blue-whale-units is still too high a figure for the stock to bear in perpetuity. The figure probably is too high and, as recorded above, the Scientific Committee of the Commission has the study of this particular point as its main present task. The most important shares in the world's whaling industry are of course still assumed by Norway and Great Britain. 